\title{
Apoptosis and its Role in Parkinson's Disease
}

\author{
Nour S. Erekat
}

Department of Anatomy, Faculty of Medicine, Jordan University of Science and Technology, Irbid, Jordan

Author for correspondence: Nour S. Erekat DDS, PhD, Department of Anatomy, Faculty of Medicine, Jordan University of Science and Technology, P.O. Box 3030, Irbid 22110, Jordan. E-mail: nserekat@just.edu.jo

Doi: http://dx.doi.org/10.15586/codonpublications.parkinsonsdisease.2018.ch4

\begin{abstract}
Parkinson's disease is one of the most common neurodegenerative diseases in the elderly. The motor symptoms occur predominantly due to substantial dopamine depletion, caused by degeneration of the dopaminergic neurons in substantia nigra pars compacta. Apoptosis has been implicated as the main mechanism of neuronal death in Parkinson's disease. Apoptosis is mediated by a number of initiator and executioner caspases, and occurs via the intrinsic or extrinsic pathways. Activation of initiator caspase-9 mediates the intrinsic pathway-also called the mitochondria-mediated pathway. Alternatively, activation of initiator caspase-8 mediates the extrinsic apoptotic pathway-the cell death receptor-mediated pathway. Both initiator caspases converge onto a common pathway of executioner caspases, involving caspase-3 and caspase- 6 . Activation of the executioner caspases leads to the morphological features characteristic of apoptosis, such as DNA cleavage and its subsequent fragmentation. Proapoptotic factors, such as Bax, have been implicated in neuronal cell death in Parkinson's disease, and there is evidence that both the intrinsic and extrinsic apoptotic pathways may play a role. This chapter provides an overview of apoptosis and its significance in Parkinson's disease.
\end{abstract}

In: Parkinson's Disease: Pathogenesis and Clinical Aspects. Stoker TB, Greenland JC (Editors). Codon Publications, Brisbane, Australia. ISBN: 978-0-9944381-6-4; Doi: http://dx.doi. org/10.15586/codonpublications.parkinsonsdisease.2018

Copyright: The Authors.

Licence: This open access article is licenced under Creative Commons Attribution 4.0 International (CC BY 4.0). https://creativecommons.org/licenses/by-nc/4.0/ 
Keywords: Apoptosis; Caspases; Neurodegenerative disease; Parkinson's disease; Programmed cell death

\section{INTRODUCTION}

Neuronal death occurs during normal development and in response to a myriad of pathological factors, such as traumatic injury (1), ischemia (2), infectious agents (3), or genetic aberrations (4). The major mechanisms by which neurons may die are apoptosis and necrosis. Apoptosis is the predominant mode of neuronal death in many neurodegenerative diseases $(5,6)$, including Parkinson's disease (7). Whilst the pathogenic processes of Parkinson's disease are not completely understood, convergent mechanisms result in neuronal death through apoptosis, making apoptotic pathways interesting potential therapeutic targets. Apoptotic cell death has been observed in cell culture and animal models of Parkinson's disease, and also in nigrostriatal regions of the brains of patients with Parkinson's disease at postmortem (8-10). This chapter provides an overview of apoptosis and its role in Parkinson's disease.

\section{APOPTOSIS}

Apoptosis - the major pathway for programmed cell death—can be initiated by a number of broad classes of death stimuli, including abnormal intracellular calcium concentrations (excitotoxicity) (11), afferent or efferent trophic factor deprivation (12), activation of death receptors (13), and stress (12). Neuronal apoptosis is common during development and maturation, and is essential for shaping of the nervous system and development of appropriate circuitry (14). Apoptosis consists of a sequence of events, which are energy dependent. It is characterized by specific morphological and biochemical changes, including shrinkage of the cell, the chromatin becoming condensed, nuclear DNA fragmentation, and formation of apoptotic bodies, which contain nuclear material. During this process, the cell membrane retains its integrity. Apoptotic bodies are eventually removed by phagocytosis, importantly without a consequent inflammatory response $(15,16)$. Biochemically, apoptosis is characterized by increased rates of protein degradation $(17,18)$ and increased caspase activity (19). The biochemical components of the apoptosis pathways were first described in genetic studies on the nematode, Caenorhabditis elegans $(20,21)$, with subsequent studies identifying the mammalian homologues (22-24). These apoptotic biochemical components are a group of molecules called the B-cell lymphoma (Bcl-2) family, apoptotic peptidase activating factor (Apaf-1), and caspases (25).

\section{Caspases}

Caspases constitute a family of at least 14 cysteine proteases that regulate apoptosis (26). Caspases are present in normal cells as inactive zymogens, which are activated in response to apoptotic stimuli. In general, a single peptide precursor is 
cleaved, via one or two chronological proteolytic steps, into an active enzyme, which consists of large and small subunits (27). Caspases can be subdivided into three functional categories: (i) inflammatory caspases- $1,-4,-5,-11,-12,-13$, and -14 , are involved in immune responses to microbial pathogens by mediating the proteolytic activation of inflammatory cytokines $(28,29)$; (ii) apoptotic initiator caspases-2, $-8,-9$, and -10 , have long pro-domains containing a caspase activation and recruitment domain (e.g., caspase -2 and -9), or a death effector domain (e.g., caspase -8 and -10); and (iii) apoptotic executioner caspases-3, -6 , and -7 , have short pro-domains. Initiator caspases, which are involved in the initiation of apoptosis, are able to carry out auto-cleavage and the cleavage and activation of common downstream executioner caspases (30). Executioner caspases do not have the ability to perform auto-cleavage, so their activation is dependent on this cleavage step. Once activated, the executioner caspases carry out the downstream events of apoptosis by cleaving a number of cellular substrates (30).

Caspases mediate several intracellular events that are important in apoptosis. These include:

(i) Disabling homeostatic and repair processes, such as DNA repair (31)

(ii) Cessation of cell cycle progression (31)

(iii) Signal amplification and inactivation of apoptosis inhibitors, through cleavage of pro- and antiapoptotic proteins (32)

(iv) Facilitation of nuclear and cytoskeletal disassembly (31)

(v) Marking dying cells for engulfment and disposal (31).

In addition, caspases have been shown to cleave $\mathrm{Ca}^{2+}$-AMPA glutamate receptors, thereby preventing $\mathrm{Ca}^{2+}$-mediated excitotoxicity and subsequent necrosis of neurons (33). Though some studies have suggested that caspases may play a role in necrotic death in some circumstances (34), in general they divert the cell to an apoptotic, rather than necrotic, fate $(33,35)$.

\section{Apoptotic pathways}

Caspase activation can be triggered by two well-characterized apoptotic pathways: the mitochondria-mediated (intrinsic) pathway (Figure 1), and the cell surface death receptor (extrinsic) pathway (Figure 2) (36). The intrinsic apoptotic pathway is mediated by members of the Bcl-2 family and the permeability transition pore (PT-pore) (Figure 1) (37). Bcl-2 is a family of proteins that possess either proapoptotic (e.g., Bax) or antiapoptotic (e.g., Bcl-2) properties. Members of this family exist on the cytoplasmic surface of mitochondria as well as many other organelles (38), and act as regulators of the PT-pore $(39,40)$. Opening of the PT-pore at contact sites between the inner and outer mitochondrial membranes results in depolarized mitochondria, loss of small molecular weight substances from the matrix, and ruptured outer mitochondrial membrane as a result of osmotic mitochondrial enlargement (41). The proapoptotic Bcl-2 family proteins induce outer mitochondrial membrane permeabilization, leading to release of cytochrome c, which normally exists in the mitochondrial intermembranous space (42). When released in the cytosol, it is bound by a protein called Apaf-1 in an ATP-dependent fashion, resulting in the formation of a multimeric Apaf-1/ cytochrome c complex. The formation of the Apaf-1/cytochrome c complex is considered the commitment event that makes caspase activation irreversible, 
Cell membrane

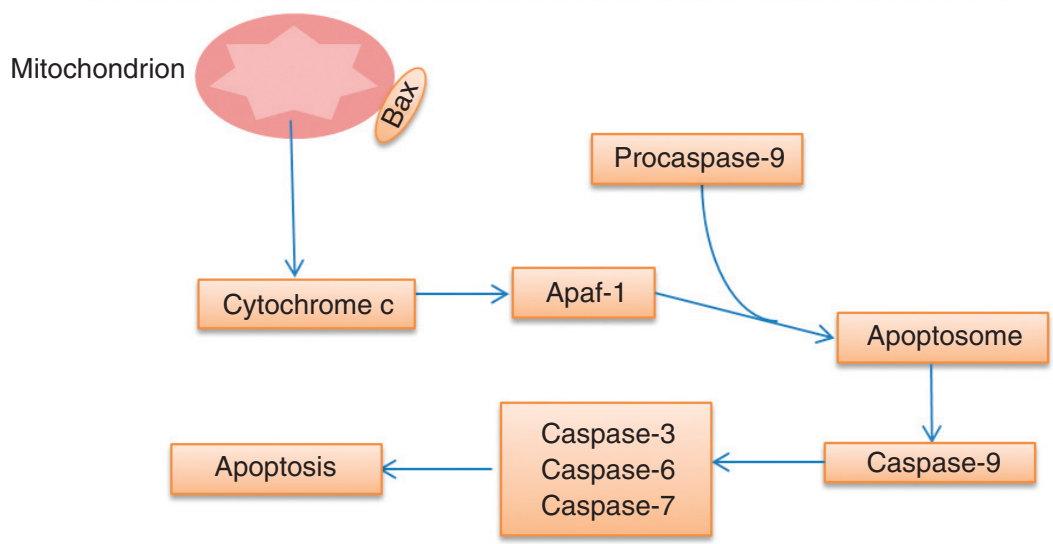

Figure 1 The intrinsic apoptotic pathway. In response to apoptotic stimuli, proapoptotic proteins, such as Bax, induce the permeabilization of the outer mitochondrial membrane, leading to release of cytochrome $\mathbf{c}$ from the mitochondrial intermembranous space. Cytochrome $\mathrm{c}$ is then bound to Apaf-1, resulting in the formation of a multimeric Apaf-1/cytochrome c complex that recruits procaspase- 9 forming the apoptosome. Consequently, procaspase- 9 is activated through proteolysis and subsequently dissociated from this complex. Once activated, caspase- 9 activates executioner caspases-3, -6 , and/or -7 , which mediate proteolytic events that eventually lead to apoptosis.

as this complex recruits procaspsase-9, resulting in formation of the apoptosome (43). Procaspase-9 is then activated through proteolysis (42). Once activated, caspase- 9 dissociates from this complex and subsequently activates executioner caspases, -3, -6, and/or -7 (43). The construction of an Apaf-1/ cytochrome c complex sets a relatively high threshold for caspase activation, preventing inadvertent commitment to apoptotic death due to leakage of cytochrome c from the mitochondria (43).

The extrinsic apoptotic pathway is dependent on the activation of cell surface death receptors (Figure 2). These constitute a group of trans-membrane proteins that belong to the tumor necrosis factor (TNF)/nerve growth factor (NGF) receptor superfamily. These receptors possess extracellular domains which include a highly conserved cysteine-rich repeat. Structurally associated molecules belonging to the TNF superfamily are the activating ligands for these death receptors (e.g., FAS ligand) (44). Binding of activating ligands to the receptors results in receptor trimerisation and recruitment of specific intracellular receptor-associated proteins, such as procaspase- 8 . Procaspase- 8 is then immediately cleaved into the active form (caspase-8) that comprises two catalytic subunits which are able to activate downstream executioner caspases (45).

The downstream steps in the apoptotic pathways are then mediated by the executioner caspases, which cleave a large number of specific substrates (46). For instance, caspase-3 and caspase-7 inhibit DNA repair by cleaving the nuclear enzyme poly(ADP-ribose) polymerase (PARP), which normally participates in DNA repair (47). Caspase-3 also degrades DNA-dependent protein kinase 


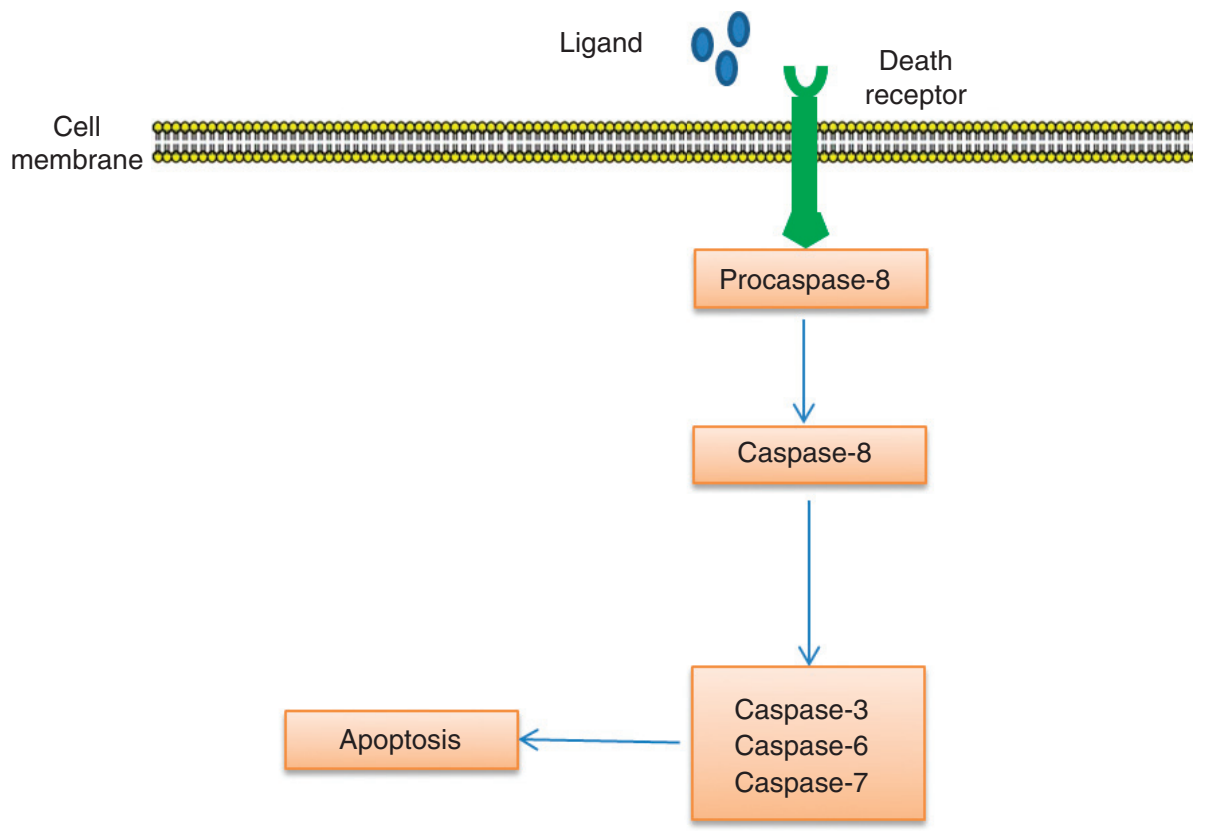

Figure 2 The extrinsic apoptotic pathway. Specific death signal ligands bind to death receptors, resulting in receptor trimerisation, and subsequent recruitment of specific intracellular receptor-associated proteins, such as procaspase-8. Procaspase-8 is then immediately cleaved into the active form, which is able to activate downstream executioner caspases-3, 6, and/or 7 that mediate proteolytic events of cellular proteins and structures eventually leading to apoptosis.

(DNA-PK), leading to reduced DNA repair capacity of the cell and subsequent promotion of the characteristic DNA cleavage that occurs in apoptosis (48). Furthermore, caspase-3 digests cytoskeletal proteins, such as actin and fodrin inducing cell shrinkage and membrane blebbing (49). Caspase-3 also leads to chromatin condensation and nuclear fragmentation through proteolytic activation of protein kinase $C$ delta (50). Caspase- 6 cleaves lamins, the main structural proteins of the nuclear envelope, resulting in nuclear shrinkage and the ultimate formation of apoptotic bodies (51). Morphological features of apoptosis include chromatin condensation, which starts peripherally along the nuclear membrane forming a ring-like structure, internucleosomal fragmentation of double-stranded DNA, and nuclear fragmentation (52). In addition, other morphological characteristics of apoptosis are membrane blebbing (53), cell shrinkage (54), and formation of apoptotic bodies, which are tightly packed with cytoplasmic organelles and nuclear fragments, and are ultimately engulfed by neighboring cells without provoking inflammation (55). The chief molecular components of apoptosis in neurons are the same as those in other nonneuronal cell types (56). 


\section{APOPTOSIS IN PARKINSON'S DISEASE}

Apoptosis is the main mechanism of neuronal loss in Parkinson's disease, as evidenced by the identification of DNA fragmentation and apoptotic chromatin changes in dopaminergic neurons of Parkinson's disease patients in postmortem studies (10). In addition, the role of apoptosis in the pathogenesis of Parkinson's disease was confirmed in postmortem and in vitro studies that illustrated elevated activity of caspase- 3 and increased expression of active caspase- 3 in substantia nigra pars compacta (57-59). Furthermore, dopaminergic neuronal death is inhibited by overexpression of anti-apoptotic proteins, such as Bcl-2, in cell models of Parkinson's disease (60). Caspase inhibitors have also been shown to rescue neurons from death in cell models of Parkinson's disease, adding further support to the notion that apoptosis is the main mechanism of neuronal death in Parkinson's disease (61). Elevated levels of proapoptotic proteins, such as Bax, have also been seen in postmortem brain tissue from Parkinson's disease patients (62).

Whilst there is some suggestion that the extrinsic apoptotic pathway may be active in Parkinson's disease, its role remains unclear. The predominant mechanism of neuronal death is thought to be the intrinsic apoptotic pathway. Mitochondria-mediated apoptosis has been extensively studied in Parkinson's disease. It involves a sequence of events including increased generation of reactive oxygen species, cytochrome c release and ATP depletion, as well as caspase-9 and caspase 3 activation (63). It remains unclear as to how the multiple pathogenic processes of PD such as alpha-synuclein ( $\alpha$-synuclein) aggregation and mitochondrial dysfunction, for example, interact with one another to converge toward apoptotic cell death. In the remainder of this section, some of the possible triggers of apoptosis in Parkinson's disease are discussed. These include the interaction of $\alpha$-synuclein with the mitochondrial membrane, the presence of nuclear DNA mutations, accumulation of mitochondrial DNA deletions, and mitochondrial dysfunction through other mechanisms (64).

$\alpha$-synuclein is abundantly expressed in the central nervous system, particularly presynaptically (65). It is prone to fibrillar aggregation forming a major component of the Lewy bodies that are the pathological hallmark of Parkinson's disease (65). $\alpha$-synuclein aggregates and inclusions are formed in Parkinson's disease brains, and rodents and cells treated with mitochondrial toxins (66-68). Accumulation of wild-type $\alpha$-synuclein in dopaminergic neurons leads to decreased activity of mitochondrial complex I and increased reactive oxygen species generation-an effect which is more pronounced by the expression of the aggregation-prone mutant A53T $\alpha$-synuclein (69). $\alpha$-synuclein has also been shown to localize to the mitochondrial membrane in SHSY cells overexpressing A53T mutant or wild-type $\alpha$-synuclein, and in isolated rat brain mitochondria (70), and this interaction has been suggested to lead to oxidative stress and the release of cytochrome c into the cytosol, in in vitro systems. Subsequent to its release into the cytoplasm, cytochrome c interacts with pro-survival, antiapoptotic proteins, triggering mitochondriamediated apoptosis $(70,71)$.

Indeed, mitochondrial dysfunction may be an early occurrence in humans and in animal models of Parkinson's disease (72-74). A defect in the activity of mitochondrial complex I has been observed in substantia nigra of Parkinson's disease 
patients (75). Dopamine metabolism leads to the generation of reactive oxygen species, which may lower the threshold for apoptotic cell death (76-78). Dopamine is enzymatically metabolized by monoamine oxidase (MAO), leading to the production of $\mathrm{H}_{2} \mathrm{O}_{2}$, which subsequently yields reactive oxygen species (76-78). Degradation products of dopamine undergo autoxidation, leading to increased reactive oxygen species generation (76-78). Hence, nigral dopaminergic neurons are particularly susceptible to dysfunction of mitochondrial complex I (79), which is believed to be one of the principal sources of reactive oxygen species in Parkinson's disease. Reactive oxygen species production may therefore represent a potential important mechanism contributing to dopaminergic neuronal death through apoptosis (80). Defects in the activity of mitochondrial complex I are proposed to increase the susceptibility of dopaminergic neurons for degeneration, through lowering of the threshold for activation of the intrinsic apoptotic pathway $(62,81-83)$.

A number of mitochondrial toxins result in selective degeneration of dopaminergic nigral neurons through apoptosis, lending support to the idea that these neurons are particularly susceptible to mitochondrial dysfunction. These include 1-methyl4-phenyl-1,2,3,6-tetrahydropyridine (MPTP), rotenone, and 6-hydroxydopamine (6-OHDA), which inhibit mitochondrial complex I causing mitochondrial dysfunction and generation of reactive oxygen species $(8,84,85)$.

Dopamine itself is suggested to inhibit mitochondrial complex I, resulting in mitochondrial dysfunction (86). It undergoes autoxidation causing the excessive production of toxic metabolites that lead to oxidative stress and mitochondrial swelling and subsequent opening of the mitochondrial transition pore, which results in the release of anti- and proapoptotic factors $(87,88)$. Hence, cytochrome $\mathrm{c}$ is released into the cytosol, where it induces the intrinsic apoptotic pathway $(87,89,90)$. It is also associated with significant increase in p53 phosphorylation, which is suggested to induce apoptosis $(91,92)$. Addition of antioxidants inhibits the activation of caspase- 9 and caspase- 3 and prevents apoptosis in response to dopamine exposure, supporting the fact that reactive oxygen species are important in dopamine-induced apoptosis $(87,90)$. Furthermore, overexpression of the antiapoptotic factor $\mathrm{Bcl} 2$ can partially attenuate dopamine-induced apoptosis (93).

MPTP is a neurotoxin that is selective to dopaminergic neurons of the substantia nigra pars compacta (94). MPTP is a lipophilic substance that actively crosses the blood-brain barrier to enter the central nervous system, where it is transformed to its active metabolite called MPP+ (1-methyl-4-phenylpyridinium) (95). This conversion is carried out by MAO that is present in the glial cells (95). Following its reuptake by dopamine transporter, MPP+ builds up in the mitochondria of dopaminergic neurons inhibiting the mitochondrial complex I, leading to ATP depletion and increased generation of reactive oxygen species $(96,97)$. As a consequence, nigrostriatal dopaminergic neurons die via apoptotic pathways involving caspases (98). MPTP-induced apoptosis is characterized by reactive oxygen species generation, cytochrome c release, p53 expression, cleavage of caspase-3, and DNA fragmentation, as well as by other morphological features characteristic for apoptosis $(59,99)$. MPTP-induced apoptosis is attenuated by overexpressed Bcl-2 levels (100, 101).

Similarly, rotenone inhibits mitochondrial complex I, resulting in the overproduction of reactive oxygen species and oxidative stress (102). Consequently, depletion in 
ATP levels occurs resulting in selective nigrostriatal dopaminergic degeneration via mitochondria-mediated caspase-dependent apoptosis (102).

6-OHDA inhibits mitochondrial complex I, induces Bax, and causes activation of caspase-3 and caspase-9 (103). 6-OHDA-induced dopaminergic neuronal degeneration is attenuated by caspase inhibitors (104). 6-OHDA also induces apoptosis that occurs via a mitochondria-dependent pathway (85). Whilst these nigral toxin models are not necessarily truly reflective of the pathogenic mechanisms that are occurring in patients, they offer insight into the susceptibility of nigral neurons to mitochondria-mediated apoptosis.

A number of inherited forms of Parkinson's disease occur due to mutations in genes related to mitochondrial health and function. These include mutations in Parkin, LRRK2, PINK1, and DJ-1, for example (105). Whilst these mutations are rare within the Parkinson's disease population, they offer some supportive evidence to the fact that nigral neurons are susceptible to mitochondrial damage and mitochondria-mediated apoptosis, and that these processes may be relevant in idiopathic Parkinson's disease.

Parkin deficiency results in mitochondrial dysfunction in mice (106). Parkin has many roles that are potentially relevant in Parkinson's disease pathogenesis. For example, it can promote mitochondrial biogenesis, mtDNA replication, and transcription of mitochondrial genes (107). Thus, Parkin is vital for mitochondrial respiration and function (107). In addition, Parkin acts as an E3 ubiquitin protein ligase that targets particular substrates for degradation via the ubiquitinproteasome system, including the glycoslyated form of $\alpha$-synuclein (108). The loss of Parkin activity is thought to contribute to the buildup of toxic protein aggregates causing Parkinson's disease (108). Interestingly, Parkin acts downstream of one of the other aforementioned genes-PINK1 - a mitochondrial kinase in which mutations can cause an autosomal recessive familial form of early onset Parkinson's disease. This is demonstrated by the fact that Parkin overexpression can compensate for mutations in PINK1 (109, 110). Whilst the mechanisms by which these mutations precipitate Parkinson's disease pathology are unclear, there is some evidence that the PINK1-Parkin pathway may play a role in susceptibility to mitochondria-mediated apoptosis. For example, upregulation of wild-type PINK1 reduces cytochrome c release and caspase activation (111, 112).

Mutations in DJ1, which is present in the mitochondrial matrix and intermembranous space, can cause early onset Parkinson's disease (113). Lack of DJ1 increases susceptibility to free radical-associated injury (114), whilst overexpression of wild-type DJ1 can be protective (115). Mutations in DJ1 result in increased oxidative stress. In addition, mutant DJ-1 binds very tightly to mitochondrial Bcl-XL, which is an antiapoptotic protein, resulting in dissociating Bax from Bcl-XL and its subsequent enrichment in the outer mitochondrial membrane, leading to the dopaminergic neuronal degeneration via mitochondria-mediated apoptosis (116).

In vitro studies have suggested a toxic gain of function brought about by LRRK2 mutations that cause Parkinson's disease (117). LRRK2 mutation can lead to defective mitochondrial morphology and dynamics and increase generation of reactive oxygen species in cells (118). LRRK2 mutations have been suggested to cause dopaminergic neuronal death by mitochondria-mediated apoptosis subsequent to mitochondrial dysfunction. Apoptosis can be induced in vitro by the 
overexpression of mutant LRRK2 with cell death being prevented by caspase inhibitors and genetic ablation of Apaf1 (61).

Mitochondrial DNA deletions have been observed in nigrostriatal dopaminergic neurons in aging and Parkinson's disease, possibly increasing their susceptibility to mitochondria-mediated apoptosis $(119,120)$. Mechanisms underlying mitochondrial DNA deletions are unknown with the possible involvement of oxidative stress (121). Combination of mitochondrial DNA depletion and deletion (without any alteration in the overall mitochondrial mass) results in reduced mitochondrial function and integrity, which increases the risk of cytochrome c release and apoptosis $(122,123)$. In addition, a rare form of inherited PD may occur due to mutations in the nuclear gene encoding DNA polymerase G (POLG), which plays an important role in the expression of a number of the genes encoded in mitochondrial DNA $(124,125)$.

\section{THERAPEUTIC IMPLICATIONS}

Given that the end-point of the Parkinson's disease pathogenic pathway is apoptotic neuronal death, treatments that target the molecular and biochemical events that allow progression of apoptosis may protect against the loss of dopaminergic neurons. As has been discussed, apoptosis is dependent on caspase activation (126). Thus, caspase inhibition has been considered as a novel therapeutic approach in neurodegenerative diseases occurring via apoptosis (126). Indeed, caspase inhibition prevents cell death of dopaminergic substantia nigra pars compacta neurons induced by MPTP or its active metabolite MPP+ in vitro and in vivo (127). However, although the dopaminergic neurons could be rescued, the nigrostriatal terminals were disrupted, suggesting that this approach may simply allow for the survival of dysfunctional neurons, suggesting that inhibition of apoptosis alone may in fact be detrimental (127). However, concomitant administration of glial cell line-derived neurotrophic factor (GDNF) circumvented this problem, allowing for restoration of striatal dopamine concentrations (127). It may therefore be feasible that caspase inhibition in combination with specific growth factors could play a role in future treatment of Parkinson's disease.

Interfering with events in the induction phase of apoptosis upstream to activation of caspases was regarded as strategy to prevent death of dopaminergic neurons and restore their function (128-132). For instance, Bax is upregulated in dopaminergic neurons subsequent to MPTP treatment (128). In addition, genetic deletion of Bax prevented dopaminergic neurodegeneration in the MPTP mouse model of nigrostriatal degeneration (128). Furthermore, Bax inhibition could decrease the loss of the nigral dopaminergic neurons that was caused by intrastriatal administration of 6-OHDA, suggesting Bax-inhibiting peptides as possible therapeutic avenue for Parkinson's disease (129).

The propargylamine derivative CGP 3466 (dibenzo[b,f]oxepin-10-ylmethylmethyl-prop-2-ynyl-amine) has been shown to possess neuro-rescuing and antiapoptotic characteristics (130). CGP3466B suppresses neuronal apoptosis by upregulating protein-L-isoaspartate (D-aspartate) O-methyltransferase (PCMT1), which is an enzyme that repairs damaged L-isoaspartyl residues in intracellular proteins. Upregulated PCMT1 leads to overexpression of the antiapoptotic Bcl-2 
and underexpression of the proapoptotic Bax and active-caspase 3 , and thus inhibiting mitochondria-dependent apoptosis (133). Concomitantly, it prevents dopaminergic cell death both in vitro and in rodent models of Parkinson's disease, and it consequently inhibits the development of MPTP- and 6-OHDA-induced motor symptoms $(131,132)$. Consequently, CGP 3466 may be promising in inhibiting dopaminergic neuron degeneration and the consequent progression of the neurodegenerative process in patients with Parkinson's disease $(131,132)$. Thus, treatments that interfere with the apoptotic pathways may represent promising therapeutic strategies in the protection against the loss of dopaminergic neurons and the subsequent pathogenesis of Parkinson's disease in the patients.

Having discussed these approaches, it must be acknowledged that there are concerns regarding the targeting of apoptosis in neurodegenerative disease. As has been discussed in this chapter, apoptosis in PD is thought to be triggered by a number of intracellular pathologies, with mitochondrial dysfunction being particularly important. Inhibition of apoptosis, therefore, may prevent the programmed removal of dysfunctional, nonviable neurons, which may ultimately lead to necrosis and a potential inflammatory response. In cell culture models of Parkinson's disease, treatment with caspase inhibitors did indeed trigger a switch from neuronal apoptosis to necrosis (134). In addition, although genetic deletion of Bax inhibited dopaminergic neuronal death in response to 6-OHDA in transgenic mice, it could not improve behavioral deficits that were associated with Parkinson's disease, and the surviving dopaminergic neurons displayed marked neuronal atrophy (135). Furthermore, systemic administration of an antiapoptotic compound may allow for the prolonged survival and accumulation of dysfunctional and potentially neoplastic cells in many tissues, which would clearly be detrimental. Thus, although apoptosis is the final step in the pathogenic pathway in PD, it remains to be seen whether or not inhibition of apoptosis in Parkinson's disease can be effective and safe, and cautious evaluation is necessary.

\section{CONCLUSION}

Apoptotic cell death is suggested to be involved in the pathogenesis of Parkinson's disease based on in vitro, in vivo, and human postmortem studies. Elucidation of the triggers of the apoptotic process in Parkinson's disease can lead to a better understanding of the sequence of events that result in programmed cell death in Parkinson's disease. Consequently, it would be possible to identify the potential factors that can be targeted therapeutically to stop or slow the progression of the disease and to recognize the individuals who are susceptible to developing Parkinson's disease at early and preclinical stages.

Conflict of interest: The authors declare no potential conflict of interest with respect to research, authorship, and/or publication of this chapter.

Copyright and permission statement: To the best of my knowledge, the materials included in this chapter do not violate copyright laws. All original sources have been appropriately acknowledged and/or referenced. 


\section{REFERENCES}

1. Joseph R. Traumatic amnesia, repression, and hippocampus injury due to emotional stress, corticosteroids and enkephalins. Child Psychiatry Hum Dev. 1998;29(2):169-85. http://dx.doi. org/10.1023/A:1025092117657

2. Choi DW, Rothman SM. The role of glutamate neurotoxicity in hypoxic-ischemic neuronal death. Annu Rev Neurosci. 1990;13:171-82. http://dx.doi.org/10.1146/annurev.ne.13.030190.001131

3. De Chiara G, Marcocci ME, Sgarbanti R, Civitelli L, Ripoli C, Piacentini R, et al. Infectious agents and neurodegeneration. Mol Neurobiol. 2012;46(3):614-38. http://dx.doi.org/10.1007/ s12035-012-8320-7

4. Valente EM, Abou-Sleiman PM, Caputo V, Muqit MM, Harvey K, Gispert S, et al. Hereditary earlyonset Parkinson's disease caused by mutations in PINK1. Science. 2004;304(5674):1158-60. http:// dx.doi.org/10.1126/science. 1096284

5. Leist M, Nicotera P. Apoptosis, excitotoxicity, and neuropathology. Exp Cell Res. 1998;239(2):183201. http://dx.doi.org/10.1006/excr.1997.4026

6. Friedlander RM. Apoptosis and caspases in neurodegenerative diseases. N Engl J Med. 2003;348:136575. http://dx.doi.org/10.1056/NEJMra022366

7. Anglade P, Vyas S, Javoy-Agid F, Herrero MT, Michel PP, Marquez J, et al. Apoptosis and autophagy in nigral neurons of patients with Parkinson's disease. Histol Histopathol. 1997;12(1):25-31.

8. Singh S, Dikshit M. Apoptotic neuronal death in Parkinson's disease: Involvement of nitric oxide. Brain Res Rev. 2007;54(2):233-50. http://dx.doi.org/10.1016/j.brainresrev.2007.02.001

9. Lev N, Melamed E, Offen D. Apoptosis and Parkinson's disease. Prog Neuro-psychopharmacol Biol Psychiatry. 2003;27(2):245-50. http://dx.doi.org/10.1016/S0278-5846(03)00019-8

10. Tompkins MM, Basgall EJ, Zamrini E, Hill WD. Apoptotic-like changes in Lewy-body-associated disorders and normal aging in substantia nigral neurons. Am J Pathol. 1997;150(1):119-31.

11. Zuo J, De Jager PL, Takahashi KA, Jiang W, Linden DJ, Heintz N. Neurodegeneration in Lurcher mice caused by mutation in delta2 glutamate receptor gene. Nature. 1997;388(6644):769-73. http:// dx.doi.org/10.1038/42009

12. Pettmann B, Henderson CE. Neuronal cell death. Neuron. 1998;20(4):633-47. http://dx.doi.org/ 10.1016/S0896-6273(00)81004-1

13. Green DR. Apoptotic pathways: Paper wraps stone blunts scissors. Cell. 2000;102(1):1-4. http:// dx.doi.org/10.1016/S0092-8674(00)00003-9

14. Oppenheim RW. Cell death of motoneurons in the chick embryo spinal cord. V. Evidence on the role of cell death and neuromuscular function in the formation of specific peripheral connections. J Neurosci. 1981;1(2):141-51. http://dx.doi.org/10.1523/JNEUROSCI.01-02-00141.1981

15. Poon IK, Lucas CD, Rossi AG, Ravichandran KS. Apoptotic cell clearance: Basic biology and therapeutic potential. Nat Rev Immunol. 2014;14:166-80. http://dx.doi.org/10.1038/nri3607

16. Liu G, Wu C, Wu Y, Zhao Y. Phagocytosis of apoptotic cells and immune regulation. Scand J Immunol. 2006;64:1-9. http://dx.doi.org/10.1111/j.1365-3083.2006.01771.x

17. Brown SB, Bailey K, Savill J. Actin is cleaved during constitutive apoptosis. Biochem J. 1997;323 (Pt 1):233-7. http://dx.doi.org/10.1042/bj3230233

18. Wang KK, Posmantur R, Nath R, McGinnis K, Whitton M, Talanian RV, et al. Simultaneous degradation of alphall- and betall-spectrin by caspase 3 (CPP32) in apoptotic cells. J Biol Chem. 1998;273(35):22490-7. http://dx.doi.org/10.1074/jbc.273.35.22490

19. Kothakota S, Azuma T, Reinhard C, Klippel A, Tang J, Chu K, et al. Caspase-3-generated fragment of gelsolin: Effector of morphological change in apoptosis. Science. 1997;278(5336):294-8. http:// dx.doi.org/10.1126/science.278.5336.294

20. Ledwich D, Wu YC, Driscoll M, Xue D. Analysis of programmed cell death in the nematode Caenorhabditis elegans. Methods Enzymol. 2000;322:76-88. http://dx.doi.org/10.1016/ S0076-6879(00)22009-0

21. Malin JZ, Shaham S. Cell Death in C. elegans development. Curr Top Dev Biol. 2015;114:1-42. http:// dx.doi.org/10.1016/bs.ctdb.2015.07.018 
22. Hengartner MO, Horvitz HR. C. elegans cell survival gene ced-9 encodes a functional homo$\log$ of the mammalian proto-oncogene bcl-2. Cell. 1994;76:665-76. http://dx.doi.org/10.1016/ 0092-8674(94)90506-1

23. Tittel JN, Steller H. A comparison of programmed cell death between species. Genome Biol. 2000;1(3):REVIEWS0003.

24. Zou H, Henzel WJ, Liu X, Lutschg A, Wang X. Apaf-1, a human protein homologous to C. elegans CED-4, participates in cytochrome c-dependent activation of caspase-3. Cell. 1997;90(3):405-13. http://dx.doi.org/10.1016/S0092-8674(00)80501-2

25. Chinnaiyan AM. The apoptosome: Heart and soul of the cell death machine. Neoplasia. 1999;1(1): 5-15. http://dx.doi.org/10.1038/sj.neo.7900003

26. Thornberry NA. The caspase family of cysteine proteases. Br Med Bull. 1997;53(3):478-90. http:// dx.doi.org/10.1093/oxfordjournals.bmb.a011625

27. Donepudi M, Grutter MG. Structure and zymogen activation of caspases. Biophys Chem. 2002;101102:145-53. http://dx.doi.org/10.1016/S0301-4622(02)00151-5

28. Kostura MJ, Tocci MJ, Limjuco G, Chin J, Cameron P, Hillman AG, et al. Identification of a monocyte specific pre-interleukin 1 beta convertase activity. Proc Natl Acad Sci USA. 1989;86(14):5227-31. http://dx.doi.org/10.1073/pnas.86.14.5227

29. Nadiri A, Wolinski MK, Saleh M. The inflammatory caspases: Key players in the host response to pathogenic invasion and sepsis. J Immunol. 2006;177(7):4239-45. http://dx.doi.org/10.4049/ jimmunol.177.7.4239

30. Chowdhury I, Tharakan B, Bhat GK. Caspases-An update. Comp Biochem Physiol B Biochem Mol Biol. 2008;151(1):10-27. http://dx.doi.org/10.1016/j.cbpb.2008.05.010

31. Nicholson DW, Thornberry NA. Caspases: Killer proteases. Trends Biochem Sci. 1997;22(8): 299-306. http://dx.doi.org/10.1016/S0968-0004(97)01085-2

32. Wolf BB, Green DR. Suicidal tendencies: Apoptotic cell death by caspase family proteinases. J Biol Chem. 1999;274(29):20049-52. http://dx.doi.org/10.1074/jbc.274.29.20049

33. Glazner GW, Chan SL, Lu C, Mattson MP. Caspase-mediated degradation of AMPA receptor subunits: A mechanism for preventing excitotoxic necrosis and ensuring apoptosis. J Neurosci. 2000;20(10):3641-9. http://dx.doi.org/10.1523/JNEUROSCI.20-10-03641.2000

34. Schwab BL, Guerini D, Didszun C, Bano D, Ferrando-May E, Fava E, et al. Cleavage of plasma membrane calcium pumps by caspases: A link between apoptosis and necrosis. Cell Death Differ. 2002;9(8):818-31. http://dx.doi.org/10.1038/sj.cdd.4401042

35. Scheller C, Knoferle J, Ullrich A, Prottengeier J, Racek T, Sopper S, et al. Caspase inhibition in apoptotic $\mathrm{T}$ cells triggers necrotic cell death depending on the cell type and the proapoptotic stimulus. J Cell Biochem. 2006;97(6):1350-61. http://dx.doi.org/10.1002/jcb.20670

36. Boatright KM, Salvesen GS. Mechanisms of caspase activation. Curr OpinCell Biol. 2003;15(6): 725-31. http://dx.doi.org/10.1016/j.ceb.2003.10.009

37. Marzo I, Brenner C, Zamzami N, Susin SA, Beutner G, Brdiczka D, et al. The permeability transition pore complex: A target for apoptosis regulation by caspases and bcl-2-related proteins. J Exp Med. 1998;187(8):1261-71. http://dx.doi.org/10.1084/jem.187.8.1261

38. Gajkowska B, Wojewodzka U, Gajda J. Translocation of Bax and Bid to mitochondria, endoplasmic reticulum and nuclear envelope: Possible control points in apoptosis. J Mol Histol. 2004;35(1):11-9. http://dx.doi.org/10.1023/B:HIJO.0000020900.86650.89

39. Godlewski MM, Gajkowska B, Lamparska-Przybysz M, Motyl T. Colocalization of BAX with BID and VDAC-1 in nimesulide-induced apoptosis of human colon adenocarcinoma COLO 205 cells. Anticancer Drugs. 2002;13(10):1017-29. http://dx.doi.org/10.1097/00001813-200211000-00006

40. Godlewski MM, Motyl MA, Gajkowska B, Wareski P, Koronkiewicz M, Motyl T. Subcellular redistribution of BAX during apoptosis induced by anticancer drugs. Anticancer Drugs. 2001;12(7):607-17. http://dx.doi.org/10.1097/00001813-200108000-00008

41. Adachi M, Ishii H. Role of mitochondria in alcoholic liver injury. Free Radic Biol Med. 2002;32(6): 487-91. http://dx.doi.org/10.1016/S0891-5849(02)00740-2

42. Green DR, Kroemer G. The pathophysiology of mitochondrial cell death. Science. 2004;305(5684): 626-9. http://dx.doi.org/10.1126/science.1099320 
43. Zou H, Li Y, Liu X, Wang X. An APAF-1-cytochrome c multimeric complex is a functional apoptosome that activates procaspase-9. J Biol Chem. 1999;274(17):11549-56. http://dx.doi.org/10.1074/ jbc.274.17.11549

44. Smith CA, Farrah T, Goodwin RG. The TNF receptor superfamily of cellular and viral proteins: Activation, costimulation, and death. Cell. 1994;76(6):959-62. http://dx.doi.org/10.1016/0092-8674(94)90372-7

45. Budihardjo I, Oliver H, Lutter M, Luo X, Wang X. Biochemical pathways of caspase activation during apoptosis. Annu Rev Cell Dev Biol. 1999;15:269-90. http://dx.doi.org/10.1146/annurev. cellbio.15.1.269

46. Salvesen GS, Dixit VM. Caspases: Intracellular signaling by proteolysis. Cell. 1997;91(4):443-6. http://dx.doi.org/10.1016/S0092-8674(00)80430-4

47. Los M, Mozoluk M, Ferrari D, Stepczynska A, Stroh C, Renz A, et al. Activation and caspase-mediated inhibition of PARP: A molecular switch between fibroblast necrosis and apoptosis in death receptor signaling. Mol Biol Cell. 2002;13(3):978-88. http://dx.doi.org/10.1091/mbc.01-05-0272

48. Ghayur T, Hugunin M, Talanian RV, Ratnofsky S, Quinlan C, Emoto Y, et al. Proteolytic activation of protein kinase $\mathrm{C}$ delta by an ICE/CED 3-like protease induces characteristics of apoptosis. J Exp Med. 1996;184(6):2399-404. http://dx.doi.org/10.1084/jem.184.6.2399

49. Maravei DV, Trbovich AM, Perez GI, Tilly KI, Banach D, Talanian RV, et al. Cleavage of cytoskeletal proteins by caspases during ovarian cell death: Evidence that cell-free systems do not always mimic apoptotic events in intact cells. Cell Death Differ. 1997;4(8):707-12. http://dx.doi.org/10.1038/ sj.cdd. 4400311

50. Kitazawa M, Anantharam V, Yang Y, Hirata Y, Kanthasamy A, Kanthasamy AG. Activation of protein kinase $\mathrm{C}$ delta by proteolytic cleavage contributes to manganese-induced apoptosis in dopaminergic cells: Protective role of Bcl-2. Biochem Parmacol. 2005;69(1):133-46. http://dx.doi.org/10.1016/j. bcp.2004.08.035

51. Ruchaud S, Korfali N, Villa P, Kottke TJ, Dingwall C, Kaufmann SH, et al. Caspase-6 gene disruption reveals a requirement for lamin A cleavage in apoptotic chromatin condensation. EMBO J. 2002;21(8):1967-77. http://dx.doi.org/10.1093/emboj/21.8.1967

52. Oberhammer FA, Hochegger K, Froschl G, Tiefenbacher R, Pavelka M. Chromatin condensation during apoptosis is accompanied by degradation of lamin $\mathrm{A}+\mathrm{B}$, without enhanced activation of cdc2 kinase. J Cell Biol. 1994;126(4):827-37. http://dx.doi.org/10.1083/jcb.126.4.827

53. Coleman ML, Sahai EA, Yeo M, Bosch M, Dewar A, Olson MF. Membrane blebbing during apoptosis results from caspase-mediated activation of ROCK I. Nat Cell Biol. 2001;3(4):339-45. http://dx.doi. org/10.1038/35070009

54. Bortner CD, Cidlowski JA. A necessary role for cell shrinkage in apoptosis. Biochem Pharmacol. 1998;56(12):1549-59. http://dx.doi.org/10.1016/S0006-2952(98)00225-1

55. Kerr JF, Wyllie AH, Currie AR. Apoptosis: A basic biological phenomenon with wide-ranging implications in tissue kinetics. Br J Cancer. 1972;26(4):239-57. http://dx.doi.org/10.1038/bjc.1972.33

56. Yuan J, Yankner BA. Apoptosis in the nervous system. Nature. 2000;407(6805):802-9. http://dx.doi. org/10.1038/35037739

57. Mogi M, Togari A, Kondo T, Mizuno Y, Komure O, Kuno S, et al. Caspase activities and tumor necrosis factor receptor Rl (p55) level are elevated in the substantia nigra from parkinsonian brain. J Neural Transm (Vienna). 2000;107(3):335-41. http://dx.doi.org/10.1007/s007020050028

58. Hartmann A, Hunot S, Michel PP, Muriel MP, Vyas S, Faucheux BA, et al. Caspase-3: A vulnerability factor and final effector in apoptotic death of dopaminergic neurons in Parkinson's disease. Proc Natl Acad Sci USA. 2000;97(6):2875-80. http://dx.doi.org/10.1073/pnas.040556597

59. Viswanath V, Wu Y, Boonplueang R, Chen S, Stevenson FF, Yantiri F, et al. Caspase-9 activation results in downstream caspase-8 activation and bid cleavage in 1-methyl-4-phenyl-1,2,3,6-tetrahydropyridine-induced Parkinson's disease. J Neurosci. 2001;21(24):9519-28. http://dx.doi.org/10.1523/ JNEUROSCI.21-24-09519.2001

60. Akao Y, Maruyama W, Yi H, Shamoto-Nagai M, Youdim MB, Naoi M. An anti-Parkinson's disease drug, N-propargyl-1(R)-aminoindan (rasagiline), enhances expression of anti-apoptotic bcl-2 in human dopaminergic SH-SY5Y cells. Neurosci Lett. 2002;326(2):105-8. http://dx.doi.org/10.1016/ S0304-3940(02)00332-4 
61. Iaccarino C, Crosio C, Vitale C, Sanna G, Carri MT, Barone P. Apoptotic mechanisms in mutant LRRK2mediated cell death. Hum Mol Genet. 2007;16(11):1319-26. http://dx.doi.org/10.1093/hmg/ddm080

62. Tatton NA. Increased caspase 3 and Bax immunoreactivity accompany nuclear GAPDH translocation and neuronal apoptosis in Parkinson's disease. Exp Neurol. 2000;166(1):29-43. http://dx.doi. org/10.1006/exnr.2000.7489

63. Fiskum G, Starkov A, Polster BM, Chinopoulos C. Mitochondrial mechanisms of neural cell death and neuroprotective interventions in Parkinson's disease. Ann N Y Acad Sci. 2003;991(1):111-19. http:// dx.doi.org/10.1111/j.1749-6632.2003.tb07469.x

64. Venderova K, Park DS. Programmed cell death in Parkinson's disease. Cold Spring Harb Perspect Med. 2012;2(8). http://dx.doi.org/10.1101/cshperspect.a009365

65. Gallegos S, Pacheco C, Peters C, Opazo CM, Aguayo LG. Features of alpha-synuclein that could explain the progression and irreversibility of Parkinson's disease. Front Neurosci. 2015;9:59. http:// dx.doi.org/10.3389/fnins.2015.00059

66. Spillantini MG, Crowther RA, Jakes R, Hasegawa M, Goedert M. alpha-Synuclein in filamentous inclusions of Lewy bodies from Parkinson's disease and dementia with lewy bodies. Proc Natl Acad Sci USA. 1998;95(11):6469-73. http://dx.doi.org/10.1073/pnas.95.11.6469

67. Betarbet R, Sherer TB, MacKenzie G, Garcia-Osuna M, Panov AV, Greenamyre JT. Chronic systemic pesticide exposure reproduces features of Parkinson's disease. Nat Neurosci. 2000;3(12):1301-6. http://dx.doi.org/10.1038/81834

68. Horvath I, Iashchishyn IA, Moskalenko RA, Wang C, Warmlander S, Wallin C, et al. Co-aggregation of pro-inflammatory S100A9 with alpha-synuclein in Parkinson's disease: Ex vivo and in vitro studies. J Neuroinflammation. 2018;15(1):172. http://dx.doi.org/10.1186/s12974-018-1210-9

69. Devi L, Raghavendran V, Prabhu BM, Avadhani NG, Anandatheerthavarada HK. Mitochondrial import and accumulation of alpha-synuclein impair complex I in human dopaminergic neuronal cultures and Parkinson disease brain. J Biol Chem. 2008;283(14):9089-100. http://dx.doi.org/10.1074/jbc. M710012200

70. Parihar MS, Parihar A, Fujita M, Hashimoto M, Ghafourifar P. Mitochondrial association of alphasynuclein causes oxidative stress. Cell Mol Life Sci. 2008;65(7-8):1272-84. http://dx.doi.org/10.1007/ s00018-008-7589-1

71. Martinez-Fabregas J, Diaz-Moreno I, Gonzalez-Arzola K, Janocha S, Navarro JA, Hervas M, et al. Structural and functional analysis of novel human cytochrome $\mathrm{C}$ targets in apoptosis. Mol Cell Proteomics. 2014;13(6):1439-56. http://dx.doi.org/10.1074/mcp.M113.034322

72. Lin MT, Beal MF. Mitochondrial dysfunction and oxidative stress in neurodegenerative diseases. Nature. 2006;443:787. http://dx.doi.org/10.1038/nature05292

73. Henchcliffe C, Beal MF. Mitochondrial biology and oxidative stress in Parkinson disease pathogenesis. Nat Clin Pract Neurol. 2008;4:600. http://dx.doi.org/10.1038/ncpneuro0924

74. Burbulla LF, Song P, Mazzulli JR, Zampese E, Wong YC, Jeon S, et al. Dopamine oxidation mediates mitochondrial and lysosomal dysfunction in Parkinson's disease. Science. 2017;357(6357):1255-61. http://dx.doi.org/10.1126/science.aam9080

75. Schapira AH, Cooper JM, Dexter D, ClarkJB, Jenner P, Marsden CD. Mitochondrial complex I deficiency in Parkinson's disease. J Neurochem. 1990;54(3):823-7. http://dx.doi.org/10.1111/j.1471-4159.1990. tb02325.x

76. Ben-Shachar D, Zuk R, Glinka Y. Dopamine neurotoxicity: Inhibition of mitochondrial respiration. J Neurochem. 1995;64(2):718-23. http://dx.doi.org/10.1046/j.1471-4159.1995.64020718.x

77. Gluck MR, Zeevalk GD. Inhibition of brain mitochondrial respiration by dopamine and its metabolites: Implications for Parkinson's disease and catecholamine-associated diseases. J Neurochem. 2004;91(4):788-95. http://dx.doi.org/10.1111/j.1471-4159.2004.02747.x

78. Hauptmann N, Grimsby J, Shih JC, Cadenas E. The metabolism of tyramine by monoamine oxidase A/B causes oxidative damage to mitochondrial DNA. Arch Biochem Biophys. 1996;335(2):295-304. http://dx.doi.org/10.1006/abbi.1996.0510

79. Yamato M, Kudo W, Shiba T, Yamada KI, Watanabe T, Utsumi H. Determination of reactive oxygen species associated with the degeneration of dopaminergic neurons during dopamine metabolism. Free Radic Res. 2010;44(3):249-57. http://dx.doi.org/10.3109/10715760903456084 
80. Dias V, Junn E, Mouradian MM. The role of oxidative stress in Parkinson's disease. J Parkinsons Dis. 2013;3(4):461-91.

81. Moon HE, Paek SH. Mitochondrial dysfunction in Parkinson's disease. Exp Neurobiol. 2015;24(2): 103-16. http://dx.doi.org/10.5607/en.2015.24.2.103

82. Vila M, Przedborski S. Targeting programmed cell death in neurodegenerative diseases. Nat Rev Neurosci. 2003;4(5):365-75. http://dx.doi.org/10.1038/nrn1100

83. Perier C, Tieu K, Guegan C, Caspersen C, Jackson-Lewis V, Carelli V, et al. Complex I deficiency primes Bax-dependent neuronal apoptosis through mitochondrial oxidative damage. Proc Natl Acad Sci USA. 2005;102(52):19126-31. http://dx.doi.org/10.1073/pnas.0508215102

84. Ziv I, Melamed E, Nardi N, Luria D, Achiron A, Offen D, et al. Dopamine induces apoptosis-like cell death in cultured chick sympathetic neurons--a possible novel pathogenetic mechanism in Parkinson's disease. Neurosci Lett. 1994;170(1):136-40. http://dx.doi.org/10.1016/0304-3940(94)90258-5

85. Gomez-Lazaro M, Galindo MF, Concannon CG, Segura MF, Fernandez-Gomez FJ, Llecha N, et al. 6-Hydroxydopamine activates the mitochondrial apoptosis pathway through p38 MAPK-mediated, p53-independent activation of Bax and PUMA. J Neurochem. 2008;104(6):1599-612. http://dx.doi. org/10.1111/j.1471-4159.2007.05115.x

86. Ben-Shachar D, Zuk R, Gazawi H, Ljubuncic P. Dopamine toxicity involves mitochondrial complex I inhibition: Implications to dopamine-related neuropsychiatric disorders. Biochem Pharmacol. 2004;67(10):1965-74. http://dx.doi.org/10.1016/j.bcp.2004.02.015

87. Jones DC, Gunasekar PG, Borowitz JL, Isom GE. Dopamine-induced apoptosis is mediated by oxidative stress and is enhanced by cyanide in differentiated PC12 cells. J Neurochem. 2000;74(6): 2296-304. http://dx.doi.org/10.1046/j.1471-4159.2000.0742296.x

88. Berman SB, Hastings TG. Dopamine oxidation alters mitochondrial respiration and induces permeability transition in brain mitochondria: Implications for Parkinson's disease. J Neurochem. 1999;73(3):1127-37. http://dx.doi.org/10.1046/j.1471-4159.1999.0731127.x

89. Lim ML, Lum MG, Hansen TM, Roucou X, Nagley P. On the release of cytochrome c from mitochondria during cell death signaling. J Biomed Sci. 2002;9(6 Pt 1):488-506. http://dx.doi. org/10.1159/000064722

90. Junn E, Mouradian MM. Apoptotic signaling in dopamine-induced cell death: The role of oxidative stress, p38 mitogen-activated protein kinase, cytochrome c and caspases. J Neurochem. 2001;78(2):374-83. http://dx.doi.org/10.1046/j.1471-4159.2001.00425.x

91. Porat S, Simantov R. Bcl-2 and p53: Role in dopamine-induced apoptosis and differentiation. Ann N Y Acad Sci. 1999;893:372-5. http://dx.doi.org/10.1111/j.1749-6632.1999.tb07858.x

92. Nakamizo A, Amano T, Zhang W, Zhang XQ, Ramdas L, Liu TJ, et al. Phosphorylation of Thr18 and Ser20 of p53 in Ad-p53-induced apoptosis. Neuro Oncol. 2008;10(3):275-91. http://dx.doi. org/10.1215/15228517-2008-015

93. Cadet JL, Harrington B, Ordonez S. Bcl-2 overexpression attenuates dopamine-induced apoptosis in an immortalized neural cell line by suppressing the production of reactive oxygen species. Synapse. 2000 Mar;35(3):228-33. PubMed PMID: 10657030. http://dx.doi.org/10.1002/(SICI)10982396(20000301)35:3<228::AID-SYN8>3.0.CO;2-\#

94. Blum D, Torch S, Lambeng N, Nissou M, Benabid AL, Sadoul R, et al. Molecular pathways involved in the neurotoxicity of 6-OHDA, dopamine and MPTP: Contribution to the apoptotic theory in Parkinson's disease. Prog Neurobiol. 2001;65(2):135-72. http://dx.doi.org/10.1016/S0301-0082(01)00003-X

95. Javitch JA, D’Amato RJ, Strittmatter SM, Snyder SH. Parkinsonism-inducing neurotoxin, N-methyl-4phenyl-1,2,3,6 -tetrahydropyridine: Uptake of the metabolite N-methyl-4-phenylpyridine by dopamine neurons explains selective toxicity. Proc Natl Acad Sci USA. 1985;82(7):2173-7. http://dx.doi. org/10.1073/pnas.82.7.2173

96. Nakamura K, Bindokas VP, Marks JD, Wright DA, Frim DM, Miller RJ, et al. The selective toxicity of 1-methyl-4-phenylpyridinium to dopaminergic neurons: The role of mitochondrial complex I and reactive oxygen species revisited. Mol Pharmacol. 2000;58(2):271-8. http://dx.doi.org/10.1124/ mol.58.2.271

97. Höglinger GU, Carrard G, Michel PP, Medja F, Lombès A, Ruberg M, et al. Dysfunction of mitochondrial complex I and the proteasome: Interactions between two biochemical deficits in 
a cellular model of Parkinson's disease. J Neurochem. 2003;86(5):1297-307. http://dx.doi. org/10.1046/j.1471-4159.2003.01952.x

98. Xia XG, Harding T, Weller M, Bieneman A, Uney JB, Schulz JB. Gene transfer of the JNK interacting protein-1 protects dopaminergic neurons in the MPTP model of Parkinson's disease. Proc Natl Acad Sci USA. 2001;98(18):10433-8. http://dx.doi.org/10.1073/pnas.181182298

99. Eberhardt O, Schulz JB. Apoptotic mechanisms and antiapoptotic therapy in the MPTP model of Parkinson's disease. Toxicol Lett. 2003;139(2-3):135-51. http://dx.doi.org/10.1016/ S0378-4274(02)00428-9

100. Yang L, Matthews RT, Schulz JB, Klockgether T, Liao AW, Martinou JC, et al. 1-Methyl-4-phenyl1,2,3,6-tetrahydropyride neurotoxicity is attenuated in mice overexpressing Bcl-2. J Neurosci. 1998;18(20):8145-52. http://dx.doi.org/10.1523/JNEUROSCI.18-20-08145.1998

101. Cao X-Q, Arai H, Ren Y-R, Oizumi H, Zhang N, Seike S, et al. Recombinant human granulocyte colony-stimulating factor protects against MPTP-induced dopaminergic cell death in mice by altering Bcl-2/Bax expression levels. J Neurochem. 2006;99(3):861-7. http://dx.doi. org/10.1111/j.1471-4159.2006.04125.x

102. Li N, Ragheb K, Lawler G, Sturgis J, Rajwa B, Melendez JA, et al. Mitochondrial complex I inhibitor rotenone induces apoptosis through enhancing mitochondrial reactive oxygen species production. J Biol Chem. 2003;278(10):8516-25. http://dx.doi.org/10.1074/jbc.M210432200

103. Singh S, Kumar S, Dikshit M. Involvement of the mitochondrial apoptotic pathway and nitric oxide synthase in dopaminergic neuronal death induced by 6-hydroxydopamine and lipopolysaccharide. Redox Rep. 2010;15(3):115-22. http://dx.doi.org/10.1179/174329210X12650506623447

104. Coelln Rv, Kügler S, Bähr M, Weller M, Dichgans J, Schulz JB. Rescue from death but not from functional impairment: Caspase inhibition protects dopaminergic cells against 6-hydroxydopamineinduced apoptosis but not against the loss of their terminals. J Neurochem. 2001;77(1):263-73. http://dx.doi.org/10.1046/j.1471-4159.2001.t01-1-00236.x

105. Klein C, Westenberger A. Genetics of Parkinson's disease. Cold Spring Harb Perspect Med. 2012;2(1):a008888. http://dx.doi.org/10.1101/cshperspect.a008888

106. Palacino JJ, Sagi D, Goldberg MS, Krauss S, Motz C, Wacker M, et al. Mitochondrial dysfunction and oxidative damage in parkin-deficient mice. J Biol Chem. 2004;279(18):18614-22. http://dx.doi. org/10.1074/jbc.M401135200

107. Zheng L, Bernard-Marissal N, Moullan N, D’Amico D, Auwerx J, Moore DJ, et al. Parkin functionally interacts with PGC-lalpha to preserve mitochondria and protect dopaminergic neurons. Hum Mol Genet. 2017;26(3):582-98.

108. Shimura H, Schlossmacher MG, Hattori N, Frosch MP, Trockenbacher A, Schneider R, et al. Ubiquitination of a new form of alpha-synuclein by parkin from human brain: Implications for Parkinson's disease. Science. 2001;293(5528):263-9. http://dx.doi.org/10.1126/science.1060627

109. Park J, Lee SB, Lee S, Kim Y, Song S, Kim S, et al. Mitochondrial dysfunction in Drosophila PINK1 mutants is complemented by parkin. Nature. 2006;441(7097):1157-61. http://dx.doi.org/10.1038/ nature 04788

110. Rohe CF, Montagna P, Breedveld G, Cortelli P, Oostra BA, Bonifati V. Homozygous PINK1 C-terminus mutation causing early-onset parkinsonism. Ann Neurol. 2004;56(3):427-31. http://dx.doi. org/10.1002/ana.20247

111. Petit A, Kawarai T, Paitel E, Sanjo N, Maj M, Scheid M, et al. Wild-type PINKl prevents basal and induced neuronal apoptosis, a protective effect abrogated by Parkinson disease-related mutations. J Biol Chem. 2005;280(40):34025-32. http://dx.doi.org/10.1074/jbc.M505143200

112. Wang HL, Chou AH, Yeh TH, Li AH, Chen YL, Kuo YL, et al. PINKl mutants associated with recessive Parkinson's disease are defective in inhibiting mitochondrial release of cytochrome c. Neurobiol Dis. 2007;28(2):216-26. http://dx.doi.org/10.1016/j.nbd.2007.07.010

113. Hague S, Rogaeva E, Hernandez D, Gulick C, Singleton A, Hanson M, et al. Early-onset Parkinson's disease caused by a compound heterozygous DJ-1 mutation. Ann Neurol. 2003;54(2):271-4. http:// dx.doi.org/10.1002/ana.10663

114. Irrcher I, Aleyasin H, Seifert EL, Hewitt SJ, Chhabra S, Phillips M, et al. Loss of the Parkinson's disease-linked gene DJ-1 perturbs mitochondrial dynamics. Hum Mol Genet. 2010;19(19):3734-46. http://dx.doi.org/10.1093/hmg/ddq288 
115. Zhou W, Freed CR. DJ-1 up-regulates glutathione synthesis during oxidative stress and inhibits A53T alpha-synuclein toxicity. J Biolog Chem. 2005;280(52):43150-8. http://dx.doi.org/10.1074/ jbc.M507124200

116. Ren H, Fu K, Mu C, Zhen X, Wang G. L166P mutant DJ-1 promotes cell death by dissociating Bax from mitochondrial Bcl-XL. Mol Neurodegener. 2012;7:40. http://dx.doi.org/10.1186/1750-1326-7-40

117. Lee JW, Cannon JR. LRRK2 mutations and neurotoxicant susceptibility. Exp Biol Med. 2015;240(6):752-9. http://dx.doi.org/10.1177/1535370215579162

118. Niu J, Yu M, Wang C, Xu Z. Leucine-rich repeat kinase 2 disturbs mitochondrial dynamics via Dynamin-like protein. J Neurochem. 2012;122(3):650-8. http://dx.doi.org/10.1111/ j.1471-4159.2012.07809.x

119. Perier C, Bender A, Garcia-Arumi E, Melia MJ, Bove J, Laub C, et al. Accumulation of mitochondrial DNA deletions within dopaminergic neurons triggers neuroprotective mechanisms. Brain. 2013;136(Pt8):2369-78. http://dx.doi.org/10.1093/brain/awt196

120. Bender A, Krishnan KJ, Morris CM, Taylor GA, Reeve AK, Perry RH, et al. High levels of mitochondrial DNA deletions in substantia nigra neurons in aging and Parkinson disease. Nat Gen. 2006;38:515. http://dx.doi.org/10.1038/ng1769

121. Reeve AK, Krishnan KJ, Elson JL, Morris CM, Bender A, Lightowlers RN, et al. Nature of mitochondrial DNA deletions in substantia nigra neurons. Am J Hum Genet. 2008;82(1):228-35. http://dx.doi. org/10.1016/j.ajhg.2007.09.018

122. Ott M, Robertson JD, Gogvadze V, Zhivotovsky B, Orrenius S. Cytochrome c release from mitochondria proceeds by a two-step process. Proc Natl Acad Sci USA. 2002;99(3):1259-63. http://dx.doi. org/10.1073/pnas.241655498

123. Liu CY, Lee CF, Hong CH, Wei YH. Mitochondrial DNA mutation and depletion increase the susceptibility of human cells to apoptosis. Ann NY Acad Sci. 2004 Apr;1011:133-45. PubMed PMID: 15126291. http://dx.doi.org/10.1196/annals.1293.014

124. Luoma PT, Eerola J, Ahola S, Hakonen AH, Hellstrom O, Kivisto KT, et al. Mitochondrial DNA polymerase gamma variants in idiopathic sporadic Parkinson disease. Neurology. 2007;69(11):1152-9. http://dx.doi.org/10.1212/01.wnl.0000276955.23735.eb

125. Dolle C, Flones I, Nido GS, Miletic H, Osuagwu N, Kristoffersen S, et al. Defective mitochondrial DNA homeostasis in the substantia nigra in Parkinson disease. Nat Commun. 2016;7:13548. http:// dx.doi.org/10.1038/ncomms13548

126. Schulz JB, Weller M, Moskowitz MA. Caspases as treatment targets in stroke and neurodegenerative diseases. Ann Neurol. 1999;45(4):421-9. http://dx.doi.org/10.1002/1531-8249(199904)45:4<421:: AID-ANA2>3.0.CO;2-Q

127. Eberhardt O, Coelln RV, Kugler S, Lindenau J, Rathke-Hartlieb S, Gerhardt E, et al. Protection by synergistic effects of adenovirus-mediated X-chromosome-linked inhibitor of apoptosis and glial cell line-derived neurotrophic factor gene transfer in the 1-methyl-4-phenyl-1,2,3,6-tetrahydropyridine model of Parkinson's disease. J Neurosci. 2000;20(24):9126-34. http://dx.doi.org/10.1523/ JNEUROSCI.20-24-09126.2000

128. Vila M, Jackson-Lewis V, Vukosavic S, Djaldetti R, Liberatore G, Offen D, et al. Bax ablation prevents dopaminergic neurodegeneration in the 1-methyl-4-phenyl-1,2,3,6-tetrahydropyridine mouse model of Parkinson's disease. Proc Natl Acad Sci USA. 2001;98(5):2837-42. http://dx.doi.org/10.1073/ pnas.051633998

129. Ma C, Pan Y, Yang Z, Meng Z, Sun R, Wang T, et al. Pre-administration of BAX-inhibiting peptides decrease the loss of the nigral dopaminergic neurons in rats. Life Sci. 2016;144:113-20. http://dx.doi. org/10.1016/j.1fs.2015.11.019

130. Waldmeier PC, Spooren WP, Hengerer B. CGP 3466 protects dopaminergic neurons in lesion models of Parkinson's disease. Naunyn Schmiedebergs Arch Pharmacol. 2000;362(6):526-37. http://dx.doi. org/10.1007/s002100000300

131. Andringa G, Cools AR. The neuroprotective effects of CGP 3466B in the best in vivo model of Parkinson's disease, the bilaterally MPTP-treated rhesus monkey. J Neural Transm Suppl. 2000(60):215-25. http://dx.doi.org/10.1007/978-3-7091-6301-6_14

132. Andringa G, van Oosten RV, Unger W, Hafmans TG, Veening J, Stoof JC, et al. Systemic administration of the propargylamine CGP 3466B prevents behavioural and morphological deficits in rats with 
6-hydroxydopamine-induced lesions in the substantia nigra. Eur J Neurosci. 2000;12(8):3033-43. http://dx.doi.org/10.1046/j.1460-9568.2000.00181.x

133. Liang F, Shi L, Zheng J, Chen S, Wang Y, Zhang J. Neuroprotective effects of CGP3466B on apoptosis are modulated by protein-L-isoaspartate (D-aspartate) O-methyltransferase/Mstl pathways after traumatic brain injury in rats. Sci Rep. 2017;7(1):9201. http://dx.doi.org/10.1038/s41598-017-08196-3

134. Hartmann A, Troadec JD, Hunot S, Kikly K, Faucheux BA, Mouatt-Prigent A, et al. Caspase-8 is an effector in apoptotic death of dopaminergic neurons in Parkinson's disease, but pathway inhibition results in neuronal necrosis. J Neurosci. 2001;21(7):2247-55. http://dx.doi.org/10.1523/ JNEUROSCI.21-07-02247.2001

135. Kim TW, Moon Y, Kim K, Lee JE, Koh HC, Rhyu IJ, et al. Dissociation of progressive dopaminergic neuronal death and behavioral impairments by Bax deletion in a mouse model of Parkinson's diseases. PLoS One. 2011;6(10):e25346. http://dx.doi.org/10.1371/journal.pone.0025346 